\title{
THE REDISCOVERY OF A PECULIAR GENUS AND SPECIES OF ORIBATIDAE.
}

\author{
By H. E. Ewing, \\ Ames, Lowa.
}

Years ago Mr. Theo. Pergande made a drawing of a very peculiar species of the order Acarina. The specimens of this species were collected by Mr. E. W. Allis, at Adrian, Mich., in October, 1885. This acarid, with many others, it appears, was found in connection with a study of the eggs and larvæ of the 17-year locust. Some time later when Mr. C. L. Marlatt was ready to publish his bulletin upon the 17 -year locust, he asked Mr. Nathan Banks to determine the Acarina for him. Mr. Banks looked over the mite figures (these were very accurately drawn, and represented beautifully the characters of the different species), and named what he could. It was $\mathrm{Mr}$. Banks' intention to describe these species when he had examined the specimens. Later he did describe some of them, but the slide of this species he could not find!

Notwithstanding the fact that this slide was never found, the figure and name of this interesting species were published in Mr. Banks' treatise on the Acarina.* Whether or not Mr. Banks thought at the time his paper was published, that this genus was good, it is hard to tell. No comment whatever, is made upon this genus or species, and in his key to the genera of the Oribatida given on the opposite page from the picture, this genus is omitted.

While looking over some slides in the cabinet of the Department of Zoology, Iowa State College, I came across a slide of this species which had the following data upon it: "In galls on elm twigs. Ames, Iowa, April 16, 1894." The slide contained about a dozen individuals well preserved but poorly mounted. I dissolved off the cover-glass and obtained the specimens without injury for my work upon the species. I found that this species represents in almost exact detail all the peculiar characters shown in Mr. Pergande's figure just referred to. These characters are given in the following pages.

*A Treatise on the Acarina, or Mites. Proc. U. S. Nat. Mus., Vol. XXVIII, p. 70, Fig. 136. 
Now in regard to the question of who is to be given credit for the genus Oripoda for which this species stands as a type. $\mathrm{Mr}$. Banks writes that he never has seen any of the individuals of this species, and that the species never has been described. Mr. Pergande was not a special student of the Acarina, and did not give a name to the species. While the author himself is the only one who has ever actually studied specimens of this species with the idea of finding out the systematic value of their characters, yet I am not responsible for the name or figure in any way. In the International Code, I can find nothing which states that the person who first describes, or in any way makes recognizable a new species or genus, must have actually seen the species he is naming or describing. Morally it does not appear proper to describe species upon secondhand information, still, some of the greatest advances in science are made in the interpretation of facts observed by others. Under these conditions, it appears to me that to give both Mr. Banks and Mr. Pergande credit for the genus and species is the best way out of the difficulty: in reality the conditions are very similar to a joint authorship.

The genus Oripoda I count as a very distinct and peculiar genus. The form and shape of the cephalothorax are entirely different from that of any other species of the Oribatidae; the queer shapes and forms of the segments of the second pair of legs represent a great exaggeration of the variations from the common type, as is shown in a few of the known species; whi'e the whole body is drawn out to such an extent as to make the creature look out of all proportion when compared with the other members of the group. The genus may be described as follows:

Gen. OripodA Banks and Pergande.

Pteromorphæ very long and narrow, extending almost the entire length of the body, and attached to the cephalothorax as well as to the abdomen. Cephalothorax very long and narrow with the sides almost parallel; covered above by a single, chitinous plate which projects slightly, like a hood, over the mouth-parts (Fig. 1). Cephalothorax completely bare above except for a single pair of bristles. Pseudostigmata entirely covered above by the pteromorphæ, and occupying an extreme postero-lateral position on the cephalothorax. Tarsi of the first two pairs of legs very short and truncate anteriorly (Figs. 5 and 
6). Femora of second legs large, flattened and with a lateral blade-like expansion (Fig. 5).

The genus for which Oripoda elongata stands as a type will occupy a place next to the genus Gymnobates Banks, a genus represented by only two species, both of which are American. It shares with this genus the elongate form of the body and the truncate nature of the tarsi of the first two pairs of legs. The pteromorphæ represent an exaggeration of the form shown in Gymnobates, being extended farther forward and united by a transverse ridge at about the middle of the cephalothorax! It differs from this genus in having an elongate, cylindrical cephalothorax, entirely devoid of either the true or the lateral lamellæ; and in the structure of the second pair of legs. The species may be described as follows:

\section{Oripoda elongata Banks and Pergande.}

Light chestnut brown.

Cephalothorax very long, cylindrical, fully twice as long as broad; sides of cephalothorax almost parallel. No lamellæ, translamella or lamellar hairs present. A superior pair of bristles present, each pectinate, almost straight and about as long as the tibia of leg $\mathrm{I}$. There is a slight, chitinous ridge connecting the two pteromorphæ, which passes transversely across the middle of the cephalothorax. Pseudostigmatic organs, short, capitate and entirely concealed by the pteromorphæ.

Abdomen cylindrical, about twice as long as broad. Pteromorphæ very long and narrow, extending the entire length of the abodmen and for about one-half the length of the cephalothorax. The abdomen bears dorsally about twenty rather small, slightly curved, pectinate bristles. There is an anterior lateral marginal pair; a dorsal pair; a posterior terminal pair; and about seven pairs situated upon or near the base of the pteromorphæ. Genital covers (Fig. 3) each about one-half as broad as long and semi-disc-shaped. They are situated over twice their length in front of the somewhat larger anal covers. Anal covers (Fig. 3) subrectangular in shape and almost approximate to the posterior margin of the ventral plate.

Anterior pair of legs extending about one-half their length in front of the tip of the cephalothorax; tarsus of leg I two-thirds as broad as long, truncate anteriorly; tibia twice as long as the 
tarsus; genual slightly over one-third as long as the tibia; femur as long as tibia; coxa almost completely hidden in its socket (Fig. 4), where it has a double hinge upon which it rotates. Second pair of legs (Fig. 5) shorter than the first and normally bent at the genual; tarsus of leg II almost as broad as long; tibia much broader distally than proximally; genual slightly longer than broad; femur of a very peculiar shape, being much flattened, with an expanded latero-ventral margin; coxa as in leg I. The last two pairs of legs are of the common type; the last extending slightly beyond the tip of the abdomen. Ungues tridactyle; dactyles equally developed. Length $0.42 \mathrm{~mm}$.; breadth $0.22 \mathrm{~mm}$.

I have examined the mouth-parts of this species in hope that they would show some peculiarities, especially since this species has a rather extraordinary habitat, but they present the typical acarid form (Fig. 1); however, they are somewhat weaker than usual. The mandibles (Fig. 2) appear to be normal. The internal anatomy presents no special peculiarities. The organs are less compact than in the common species, as would be expected, because of the drawn-out form of the body. The ventriculus, or stomach, and its cæca appear to be rather small, but this is probably due to the shrinking of the tissues. In the females often there can be seen several large developing ova. The ovipositor is rather longer than usual.

\section{Explanation of Plate XXix.}

FIG. 1. Mouth-parts as seen from below.

Fig. 2. Side view of one of the mandibles.

FIG. 3. Ventral surface of the body.

Fig. 4. The coxæ of legs I and II as seen from below, so as to show their doublehinged arrangement.

FIG. 5. Inside of leg II.

FIg. 6. Tarsus and tibia of leg I. 


\section{$2 \mathrm{BHL}$ Biodiversity Heritage Library}

Ewing, H. E. 1910. "The Rediscovery of a Peculiar Genus and Species of Oribatidae." Annals of the Entomological Society of America 3, 209-212. https://doi.org/10.1093/aesa/3.3.209.

View This Item Online: $\underline{\text { https://www.biodiversitylibrary.org/item/38713 }}$

DOI: https://doi.org/10.1093/aesa/3.3.209

Permalink: https://www.biodiversitylibrary.org/partpdf/193748

\section{Holding Institution}

Smithsonian Libraries

\section{Sponsored by}

Smithsonian

\section{Copyright \& Reuse}

Copyright Status: NOT_IN_COPYRIGHT

This document was created from content at the Biodiversity Heritage Library, the world's largest open access digital library for biodiversity literature and archives. Visit BHL at https://www.biodiversitylibrary.org. 